\title{
THE EVALUATION OF ATTRACTIVENESS OF TOURISM PRODUCTS IN THE WARMIA AND MAZURY IN POLAND
}

\author{
IWONA MICHALINA BATYK ${ }^{1}$ ANETA ZOFIA DĄBROWSKA ${ }^{2}$
}

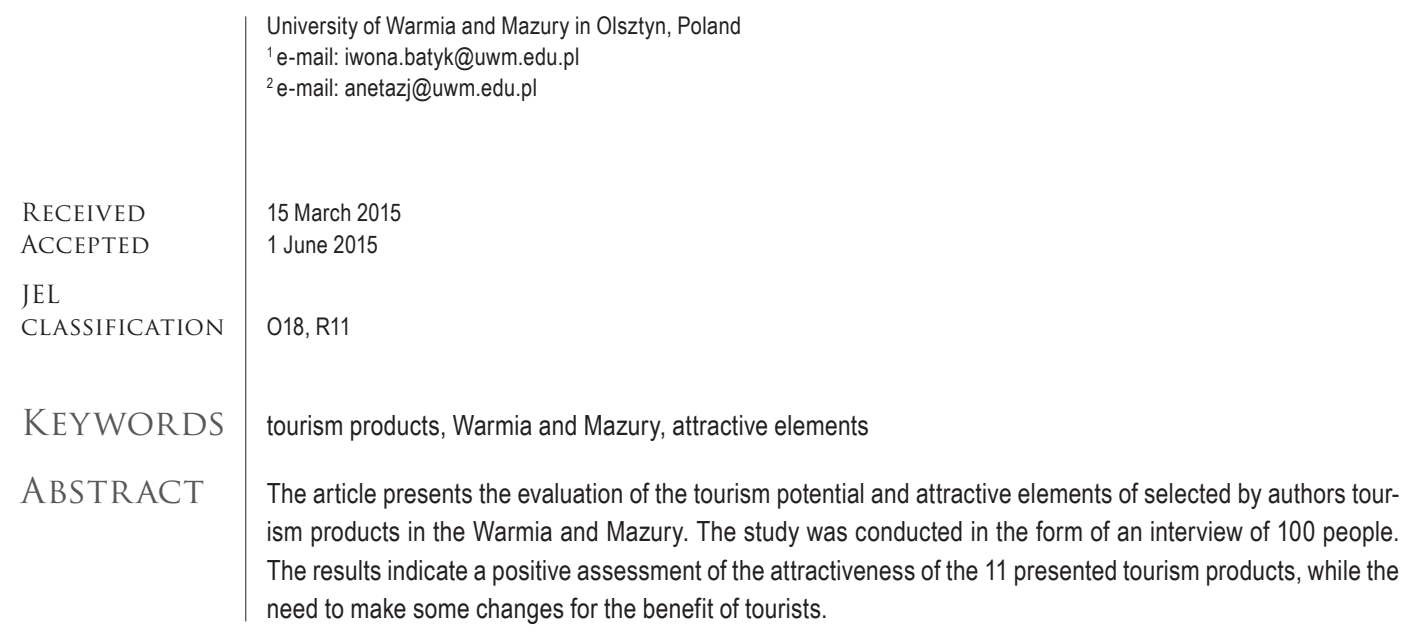

\section{Introduction}

The tourism product is a category which determines the specificity of action of a strong tourism market. It is the result of the operation of the tourist economy. The tourism product is seen in two aspects narrow and wide-called zonal (Panasiuk, 2008). Research Polish Tourism Development Agency on the tourist attractiveness of regions indicate that the Warmia and Mazury belongs to the most attractive regions in Poland (third place in Poland) 
(Bartkiewicz et al., 2010). The most popular tourist products in Warmia and Mazury are: the Great Masurian Lakes, the cruise on the Elblagg Canal, kayaking on the Krutynia River, staging Battle of Grunwald, "Wolf's Lair" - the ruins of Adolf Hilter's war headquarters in Gierłoż, famous Marian Sanctuary in Święta Lipka, The Folk Architecture Museum and Ethnographic Park in Olsztynek, Elk Narrow Gauge Railway, Gothic Castles Route, Copernicus Route and Mazury Channel.

\section{The Great Masurian Lakes}

Masurian Lake District is a group of lakes in the central part of the Mazury Lake District located in the area between Węgorzewo, Giżycko, Orzysz, Pisz, Ruciane-Nida, Nicks and Ryn (Jurak and Harajda, 2008). Poland (except Scandinavia), as the only country in Europe, has a rich diversity of lakes where you can practice all kinds of water tourism. In the eighteenth and nineteenth centuries built channels between lakes (Dylewski, 2007). Currently shipping routes are about $200 \mathrm{~km}$ and the longest channel is Channel Jegliński Land, which connects Seksty Lake of Roś Lake, opening the way to Pisz water and then into the Vistula (Warmia-Mazury Regional Tourism Organization, 2010). Here are a number reserves mainly to protect waterfowl. One of the protected areas is Łuknajno Lake inhabited by the largest colony of mute swan in Europe. Łuknajno reserve is on the list of UNESCO International Biosphere Reserves (Dylewski, 2007).

The biggest promotion of the Masurian Lake District was the competition for the New 7 Wonders of Nature, which gave the global recognition to Mazury Lakes.

\section{The cruise on the Elblag Canal}

Elblag Canal until 1945 called Oberland Canal was designed primarily for water transport. Currently, it is used for tourism and is very popular among tourists. Currently it is the longest navigable channel in Poland, with a total length of $150 \mathrm{~km}$, including branches and lakes (Harajda et al., 2010). Elblag Canal connecting Elblag with Ostróda is not only water route but also the world of engineering monument. There are the world's only operating ramps that are used to overcome the difference in water levels of 104 meters (Szynkowski, 2001). Ships overcome differences due to runners rail height. Two-way ramps allow transport ships on land simultaneously in both directions. This attraction was designed by German engineer Georg Jakob Steenke in the mid-nineteenth century. Canal built in the years 1844-1872 was officially opened in 1860, has been repeatedly modernized (Harajda et al., 2010).

Overcoming the entire route from Ostróda to Elblag is 11 hours, defeating each ramp is a quarter (Pasieczny et al., 2009). From Całuny Nowe to Buczyniec ship goes over two kilometers on land (Jurak, 2008).

\section{Kayaking on The Krutynia River}

Krutynia River canoe trail starts in Sorkwity on the Lampackie lake and ends in Ruciane - Nida. The over 100 $\mathrm{km}$ of water route goes through scenic areas where you can meet valuable fauna and flora. The landscape also is diversified with forest lakes or larger lake with islands. More than a dozen lakes on the route are connected by rivers, of which the longest is the river Krutynia $26 \mathrm{~km}$ in length. On the river is 10 boathouses Polish Tourist Association. Riversite hostels offer accommodating and dining with regional cuisine (Kopyść, 2011). 


\section{Staging of The Battle of Grunwald}

In 1410 the July 15, under the Tannenberg was fought the greatest battle of medieval Europe by the combined forces of the Polish Kingdom of the Duchy of Lithuania against the Teutonic Order. The fight ended with a victory for Polish, Lithuanian and Tatar united armies. In the fields of Grunwald the commander of the Teutonic Order - Ulrich von Jungingen was killed (Nadolski, 2008). To commemorate the event in 1960 in the fields of Grunwald is a statue was made, near which there is the Museum of the Battle of Grunwald (Mydlińska, 2007).

For several years, on 15th July is traditionally played staging of the battle from 1410. In this historic event takes part 1500 knights watched by about 80-thousandth of the audience. Every year this group of viewers expands. During the Days of Grunwald, you can also explore the village with many brotherhoods of knights, participate in games, pastimes and buy souvenirs (Jurak and Harajda, 2008).

\section{"Wolf's Lair" - the ruins of Adolf Hillter's war headquarters in Gierłtoi}

"Wolf's Lair" is a group of bunkers, which is the former seat of the Third Reich led by Adolf Hitler. Bunkers were built in the years 1940-1944 as a chemical plant, whose purpose was to confuse the opponent (Klimczak, Kiełsznia and Żukowski, 2011). In Gierłoż among lakes and forests, huge buildings were created as centers of command during World War II. Among the facilities there are 7 shelters - heavy bunkers with double walls with a thickness of $8 \mathrm{~m}$, and the ceilings are $10 \mathrm{~m}$. There have been here a failed assassination attempt on Hitler. In 1945, wanting to destroy the German sappers blew his Wolf's Lair in the air. Currently, the place is secured and made available to visitors (Siemiński 1995).

\section{Marian Sanctuary in Świẹta Lipka}

Marian Sanctuary in Święta Lipka is a baroque church built on 10,000 alder piles. The idea behind the hill shrine of the fourteenth century was lime, which showed a figure of the Virgin and Child. The present church was built at the end of the seventeenth century (Polska pełna uroku..., 2008).

The church is decorated with beautiful frescoes, sculptures in wood and stone, paintings on canvas and products woodcarving and goldsmith. The Basilica is surrounded by cloisters with four identical chapels. The main gate of the motif showing twisted acanthus leaves is an artistic work of blacksmithing, which can be seen commonly in Poland. Summer attraction is the organ concerts in which to move prospectus action figures depicting the scene of the Annunciation. Church organ from the years 1719-1721, since that time have been repeatedly devastated, but the renovation allowed to restore their former glory (Paszenda, 2001).

\section{The Follk Architecture Museum and Ethnographic Park in Olsztynek}

The Folk Architecture Museum and Ethnographic Park in Olsztynek covers an area of 60 hectares. The museum was moved from Königsberg (now Kaliningrad) to Olsztynek in the 1938-1942 years. It is one of the oldest and largest of its kind in Poland. There are objects of wooden architecture of Warmia, Mazury, Vistula, and Lithuania: the church, a smithy, a tavern and rural homesteads. Around the house are gardens with plants, which formerly cultivated fields and you can also see the windmills, which formerly mills (Łodzińska, Wieczorek, Kulczyk and Kryciński, 2008). 


\section{Ełk Narpow Gauge Railway}

Elk Narrow Gauge Railway was built between 1910-1917. It is a single-track line having a $48 \mathrm{~km}$ long and $0.75 \mathrm{~m}$ wide. Wagons pulled by cable steam locomotive. Trail running from Elk to Turow. At the station in Elk there is a small railway museum. In 1992 Elk Narrow Gauge Railway was inscribed on the list of old technology (Klimczak et al., 2011).

\section{Trail of Gothic Castles}

On the Trail of Gothic Castles are 12 fortres of the Vistula, Kashubian and Warmia and Mazury. Buildings were built in the fourteenth and fifteenth centuries and their characteristic feature is the red roofs and walls made of red bricks. Half of them are in the Warmia-Mazury, 5 castles are in the Pomeranian province and one in the Kuyavian - Pomeranian province. They serve a variety of functions, there are hotels, restaurants, museums, libraries. The Route of Brick Gothic castles within the Warmia-Mazury province is: Ostróda, Nidzica, Olsztyn, Lidzbark Warminski, Kętrzyn, Ryn. In the area of Gothic Castles Route, there are other castles or their ruins (Łodzińska et al., 2008).

\section{Copernicus Route}

Copernicus Route length is $302 \mathrm{~km}$, runs not only the places where lived Nicolaus Copernicus, but also where are mementos of him. The trail begins and ends in Olsztyn, where the astronomer lived for five years. It leads by Dobre Miasto, Lidzbark Warminski, Orneta, Pieniężno, Braniewo and Frombork. In Tolkmicko and Pasłęk are historic memorabilia of the astronomer. Along the route there are also: Elblag, Małdyty and Morag (Łodzińska et al., 2008).

\section{Mazury Channel}

Mazury Channel is located in the north of Warmia and Mazury and in Russia (Kaliningrad Oblast). Its construction started in 1911, but in spite of progress in $90 \%$ it was not completed. The idea was to combine the construction of a Great Masurian Lakes via the Vistula Lagoon to the Baltic Sea. Channel with a width of 25 meters has original technical solutions. Water flows in artificial pits beating about 111 meter difference in height between Mamry Lake and Lyna River through the lock. (Harajda et al., 2010).

\section{Methods}

The paper presents an inventory of tourism products of Warmia and Mazury, and the results of field studies aimed at:

- the assessment of the tourism potential of the Warmia and Mazury,

- identification of forms of active recreation, which the tourists benefited in the region,

- recognition of the reasons for coming to the region,

- the assessment of the attractiveness of selected tourism products in Warmia and Mazury province.

The survey was conducted in the province of Warmia and Mazury in 2011 among 100 Polish respondents who had knowledge about tourism products described in this article. The method of research was carried out by direct interview using a questionnaire containing 11 questions. 
Women prevailed among the respondents (64\%), men accounted for $36 \%$. The vast majority of people were aged $18-30$ and had $77 \%$. Among the 100 people $63 \%$ had higher education, $34 \%$ secondary education and only $3 \%$ were vocational school. A small difference was in the origin of people, $55 \%$ declared that they lived in the Warmia and Mazury, $45 \%$ of respondents came from the Podlasie, Mazovia, West Pomerania, Pomerania and Bydgoszcz, and Kielce.

\section{Results}

Respondents evaluated the specific elements of tourism potential. They could give a very good, good, satisfactory and unsatisfactory marks to different elements of tourism potential: accommodation base, catering base, tourist attractions, attractive environment, road infrastructure, signage of tourism, sales and services, information and promotion.

The attractiveness of the environment was estimated to be very good. Such answer was indicated by $69 \%$ of respondents. Road infrastructure received the worst evaluation (16\% of respondents). Accommodation and attractive environment have not received unsatisfactory grades. The signage of tourism and road infrastructure were marked as sufficient, and accommodation, catering service, tourist attractions, trade and services and information and promotion were evaluated mostly good.

Among the forms of active recreation, the respondents most frequently used in the province of WarmiaMazury mostly swimming (20\% of responses) and hiking (19\%) were indicated. Indicated forms often included the active recreation Canoeing, cycling and fishing, sailing and horse riding. The smallest success enjoyed hunting and diving, benefiting the $2 \%$ of respondents.

The most common motive for coming to the Warmia and Mazury was rest and recreation, as determined by $34 \%$ of respondents, and visiting family, friends, declared by $23 \%$ of respondents. Only $2 \%$ of respondents motive for coming to the region were business trips.

The Polish Tourist Organization shows on the basis of research conducted in 2010, that leisure was the purpose of Mazury visiting confirmed by $66 \%$ of tourists and Warmia visiting was confirmed by $58 \%$ respondents, respectively (Polish Tourist Organisation, 2010).

The next questions related to specific tourism products of Warmia and Mazury, which include: the Great Masurian Lakes, the cruise on the Elblagg Canal, kayaking on the Krutynia River, staging the Battle of Grunwald, "Wolf's Lair" - the ruins of Adolf Hilter's war headquarters in Gierłoż, famous Marian Sanctuary in Święta Lipka, The Folk Architecture Museum and Ethnographic Park in Olsztynek, Elk Narrow Gauge Railway, Gothic Castles Route, Copernicus Route and Mazury Channel. The number of tourist visiting mentioned above products is not countable, because collecting of the statistical data is not possible in same causes eg. nobody is able to count tourists at: Elblagg Canal, the Krutynia River, the Battle of Grunwald, Gothic Castles Route, Copernicus Route and Mazury Channel.

According to the survey most respondents in the region visited the Great Lakes (98\%), the Marian Sanctuary in Święta Lipka - 67\%, "Wolf's Lair" - the ruins of Adolf Hilter's war headquarters in Gierłoż - 54\% and The Folk Architecture Museum and Ethnographic Park in Olsztynek - 53\%. Elk Narrow Gauge Railway was the least popular among tourists (22\%).

Assessment of the attractiveness of selected tourism products in Warmia-Mazury province concerned following elements: values of the environment, tourism infrastructure, transport accessibility, price, tourist information. 
In terms of the assessment of the environmental values of the highest grade received the Great Lakes $(80 \%$ of responses). Kayaking on the Krutynia River was very well evaluated product (71\%). Five products received the worst marks: "Wolf's Lair" - the ruins of Adolf Hilter's war headquarters in Gierłoż, Marian Sanctuary in Święta Lipka, Gothic Castles Route, Mazury Channel and Elk Narrow Gauge Railway ( $9 \%$ negative evaluations).

As indicated by research conducted by the Polish Tourist Organisation among Polish tourists, Warmia and Mazury are known for environmental qualities, mainly lakes (Warmia - $48 \%$, Mazury $-77 \%$ of responses) and water sports (respectively $56 \%$ and $93 \%$ ). Respondents indicated the wide range of accommodation (Mazury - 61\%, Warmia -33\%), diversified offer of catering services (respectively $54 \%$ and $33 \%$ ) and a well-developed recreational activities offer (respectively $59 \%$ and $31 \%$ ). The best known the tourist products of Warmia and Mazury were: the Great Mazury Lakes - 73\% and Gothic Castles Route - 37\% (Polish Tourist Organisation, 2010).

Tourism infrastructure has been evaluated best for kayaking on the Krutynia River (48\% very good ratings). Gothic Castles Route received a negative note (12\%). Among the 11 evaluated tourism products from Warmia and Mazury, the best were: the cruise on the Elblag Canal, The Folk Architecture Museum and Ethnographic Park in Olsztynek, "Wolf's Lair" - the ruins of Adolf Hilter's war headquarters in Gierłoż , kayaking on the Krutynia River and staging the Battle of Grunwald.

Transport accessibility to tourism products was evaluated well by the majority of the respondents. The most very good notes (36\%) received: Elk Narrow Gauge Railway and staging of the Battle of Grunwald, which also received the most unsatisfactory ratings $-13 \%$. Only the "Wolf's Lair" - the ruins of Adolf Hilter's war headquarters in Gierłoż did not receive any unsatisfactory marks in terms of the availability of communication.

The respondents positively evaluated price of the products. Elk Narrow Gauge Railway has been rated the best (41\%). The cruise on the Elblag Canal for $13 \%$ of respondents was too expensive.

The best tourist information of the respondents had a staging of the Battle of Grunwald ( $67 \%$ of very good), while the worst rated was tourist information about Copernicus Route, which received $8 \%$ of unsatisfactory grades. Tourist information in overall rating of tourist products fell at a good level.

\section{Conclusions}

Warmia and Mazury is known as the "Land of a Thousand Lakes", which are the pride of tourism in the region. Results of this study indicated that tourists visiting the Warmia and Mazury were attracted other tourism products related to historical events, such as: "Wolf's Lair" - the ruins of Adolf Hilter's war headquarters in Gierłoż or sacred places, which is the Marian Sanctuary in Święta Lipka. However, not all elements of the tourism potential met their expectations. As indicated by the majority of respondents road infrastructure was not on the top level.

Although the most common motive for coming to the region was rest and recreation, not everyone was happy with the attractiveness of selected tourism products. The most negative evaluations were granted such elements as: the price of the cruise on the Elblag Canal, the availability of communication staging the Battle of Grunwald and Road Copernicus tourism infrastructure. These results should be taken into consideration during development of tourism products. 


\section{Referencess}

Bartkiewicz, P., Krajewska, A., Magda, I., Nazarczuk, J.M. \& Pelle, D. (2010). Warmia i Mazury 2020 - Jaka droga do rozwoju? Olsztyn: Instytut Badań Strukturalnych.

Dylewski, A. (2007). Warmia i Mazury. Warszawa: Świat Książki.

Harajda, S., Liżewska, I. \& Młynarczyk, K. (2010). Kanon krajoznawczy Warmii i Mazur. Olsztyn: Pracownia Wydawnicza EISet.

Jurak, M. (2008). Miejsca z klimatem. Noclegi z klasą. Warmia i Mazury. Olsztyn: Agencja WIT Witold Mierzejewski.

Jurak, M. \& Harajda, S. (2008). Warmińsko-mazurskimi szlakami. Olsztyn: Agencja WIT Witold Mierzejewski.

Klimczak, J., Kiełsznia, M. \& Żukowski, M. (2011). Rozwój inwestycji turystycznych na wybranych obszarach Krainy Wielkich Jezior Mazurskich. Warszawa: Oficyna Wydawnicza ASPRA-JR.

Kopyść, K. (2011). Szlak kajakowy rzeki Krutyni. Olsztyn: Mazury PTTK.

Łodzińska, E., Wieczorek, W., Kulczyk, S. \& Kryciński, S. (2008). Polska niezwykła województwo warmińsko-mazurskie. Warszawa: Demart.

Mydlińska, A. (2007). Mazury. Białystok: Wyd. Agencja Reklamowo-Wydawnicza ART.

Nadolski, A. (2008). Grunwald 1410. Warszawa: Bellona.

Panasiuk, A. (2008). Produkt turystyczny. In:Gospodarka turystyczna. Ed. A. Panasiuk. Warszawa: PWN.

Pasieczny, R., Bajcar, A. \& Omilanowska, M. (2009). Atrakcje turystyczne Polski od A do Z. Warszawa: Multico Oficyna Wydawnicza. Paszenda, J. (2001). Święta Lipka. Przewodnik. Święta Lipka: Klasztor 0.0. Jezuitów.

Polish Tourist Organisation. (2010). Badanie skuteczności kampanii promocyjnej walorów turystycznych Polski Wschodniej. SopotWarszawa: PBS DGA.

Polska pełna uroku. Wędrówki z pasją. (2008). Ed. R. Brzezińska. Warszawa: Petit Fute - Polska.

Siemiński, S. (1995). Wilczy Szaniec. Kętrzyn: Bartograf.

Szynkowski, J. (2001). Reiseführer Masuren. Land der dunklen Wälder und kristall'nen Seen. Kętrzyn: Kengraf.

Cite this article aS: Batyk, I.M., Dąbrowska, A.Z. (2015). The evaluation of attractiveness of tourism products in the Warmia and Mazury in Poland. Szczecin University Scientific Journal, No. 872. Service Management, 15 (1): 23-29. 
